\title{
Dominant curly coat in horses
}

\author{
DP Sponenberg \\ Virginia-Maryland Regional College of Veterinary Medicine, \\ Department of Pathology, Virginia Tech, Blacksburg, VA 24061, USA
}

(Received 18 January 1989; accepted 20 December 1989)

Summary - Records from the American Bashkir Curly Horse Registry indicate that of 457 registered horses, 25 had no curly-coated parents and this occurred in purebreds of breeds where curliness is rare, 224 had 1 curly coated parent, 122 had 2 curly coated parents, and 86 had parents of unknown status. Complete production records on some individuals have revealed that matings between curly coated horses produced 47 curly coated and 11 normal coated offspring. Matings between curly and normal coated horses produced 29 curly and 17 normal coated offspring. The results are consistent with a dominant gene causing curly coat in horses, although a separate previously documented recessive gene for curliness also exists. The symbol $C r d$ for dominant curliness is suggested for the dominant gene.

horse / curly coat

Résumé - Dominance de la robe à poils bouclés chez le cheval . L'analyse des 457 dossiers de l'American Bashkir Curly Horse Registry a montré que 25 chevaux provenaient de parents sans robe bouclée, 224 avaient un parent à robe bouclée, 122 avaient les deux parents à robe bouclée et 86 provenaient de parents chez lesquels cette information était inconnue. Les 25 chevaux issus de parents sans robe bouclée appartenaient à des races où la robe bouclée est rare. Une étude détaillée de certains dossiers a révélé que l'accouplement entre chevaux à robe bouclée a produit 47 chevaux d̀ robe bouclée et 11 chevaux d̀ robe normale, tandis que l'accouplement entre chevaux à robe bouclée et chevaux à robe normale a produit 29 chevaux à robe bouclée et 17 à robe normale. Ces résultats indiquent la présence d'un gène dominant causant la robe bouclée bien qu'un gène récessif ait été décrit antérieurement. Le symbol Crd est suggéré pour le gène dominant responsable de la robe à poils bouclés.

cheval / robe bouclée

\section{INTRODUCTION}

Horses having a curly coat instead of the usual straight hair coat have been documented as resulting from a recessive gene in Percheron horses (Blakeslee et al, 1943). A further report concerning curliness of Lokai horses has appeared in Animal Breeding Abstracts (Shchekin and Kalaev, 1941). This report states that such curliness is recessive, but goes on to indicate that curly $\times$ curly matings produced 46 curly and 13 normal coated foals, and curly $\times$ normal coated matings produced 17 curly and 20 normal coated foals. These data are more consistent with 
Table I. Result of all matings of certain curly horses. $\chi^{2}$ are calculated under the hypothesis that the parents are heterozygous for the postulated dominant Curly gene.

\begin{tabular}{lcccc}
\hline & \multicolumn{4}{c}{ Offspring } \\
Mating type & Curly & Normal & Total & $\chi^{2}$ \\
\hline Curly x curly & 47 & 11 & 58 & 1.126 \\
Curly $\times$ normal & 29 & 17 & 46 & 3.130 \\
\hline
\end{tabular}

a dominant mode of inheritance $\left(\chi^{2}=0.277,1 \mathrm{df}, P>0.05\right.$ for curly $\times$ curly matings, $\chi^{2}=0.243,1 \mathrm{df}, P>0.05$ for curly $\times$ normal matings). In the translated abstract mention is made of the fact that "about one third of curly offspring from matings of curly parents show a more marked degree of curliness at birth, and it is thought that these may be homozygotes." It is possible that the abstract was mistranslated, and that the original stated that the curliness is dominant.

\section{MATERIALS, METHODS AND RESULTS}

The data presented are those of the records of the American Bashkir Curly Horse Registry. These horses are registered on the basis of a curly coat. Of 457 registered horses, 224 had 1 curly and 1 normal parent (curly sires produced 74 curly colts and 84 curly fillies, curly dams produced 36 curly colts and 30 curly fillies), 122 had 2 curly parents (63 curly colts and 59 curly fillies), 25 had 2 normal coated parents (12 curly colts and 13 curly fillies), and 86 were of unknown parentage. Most of these 457 originated in feral herds in the West of the USA or were the products of crossing curly feral horses with established normal haired breeds (Quarter Horse, Appaloosa, Paint). These curly horses are said to have other phenotypic similarities, such as bulging foreheads, slanting sleepy eyes, small nostrils and a peculiar odour. Some normal coated horses of these lines also have some of the same phenotypic characters so these may not be pleiotropic effects of the gene for curliness. One difference between normal coated horses and some of the curly ones is that the mane and tail hairs of some but not all of the curly horses are shed in springtime along with the thick winter body coat. This phenomenon only occurs in some individuals. The 25 curly horses resulting from matings of parents with normal coats occurred in normal coated breeds ( 1 Tennessee Walking Horse, 11 Missouri Foxtrotters, 2 Appaloosas, 4 Quarter Horses, 1 Standardbred, 1 Paso Fino and 12 others). These and the other curly types cannot be reliably distinguished by phenotype.

Complete results of matings were available for some individual animals (table I). Curly $\times$ curly matings resulted in 47 curly and 11 normal coated animals. If these are heterozygous for a dominant gene then $\chi^{2}=1.126,1 \mathrm{df}, P>0.05$. Curly $\times$ normal coat matings produced 29 curly and 17 normal haired offspring. If these curly horses are heterozygous for a dominant gene then $\chi^{2}=3.13,1 \mathrm{df}$, $P>0.05$. These results are consistent with the action of a dominant gene causing curly coat in horses, as are the Russian data. Sex linkage is not present, as indicated by the studbook data in which both colts and fillies are produced by a single curly parent of either sex. 


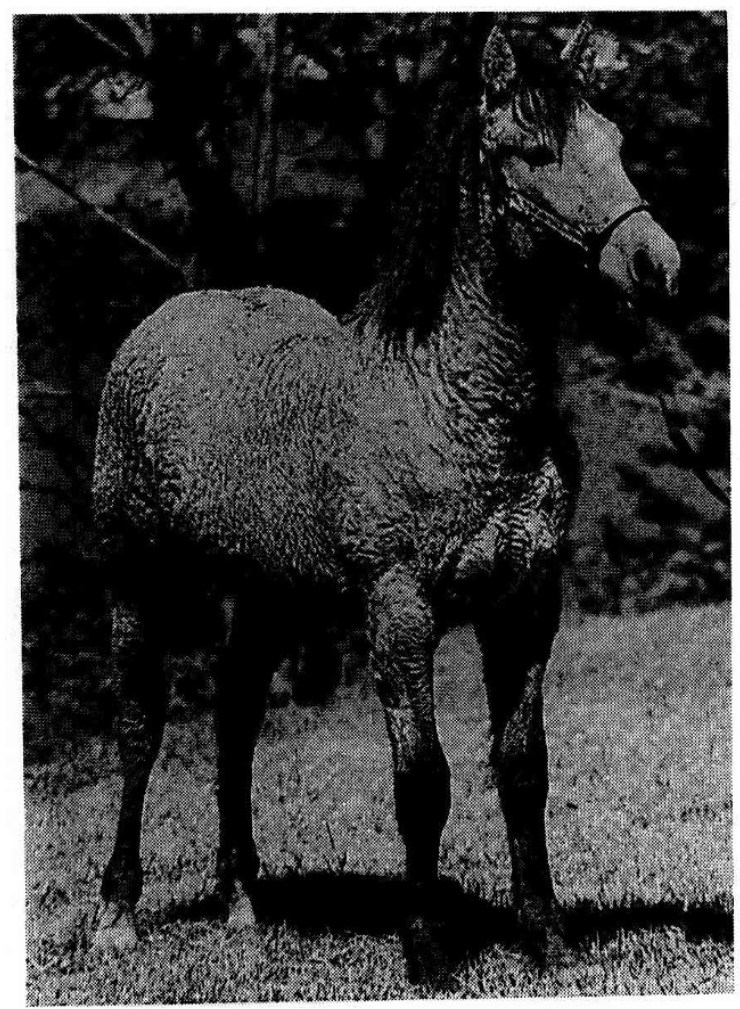

Fig 1. Curly coated horse with extreme curliness.

Fig 2. Curly coated horse with minimal curliness.

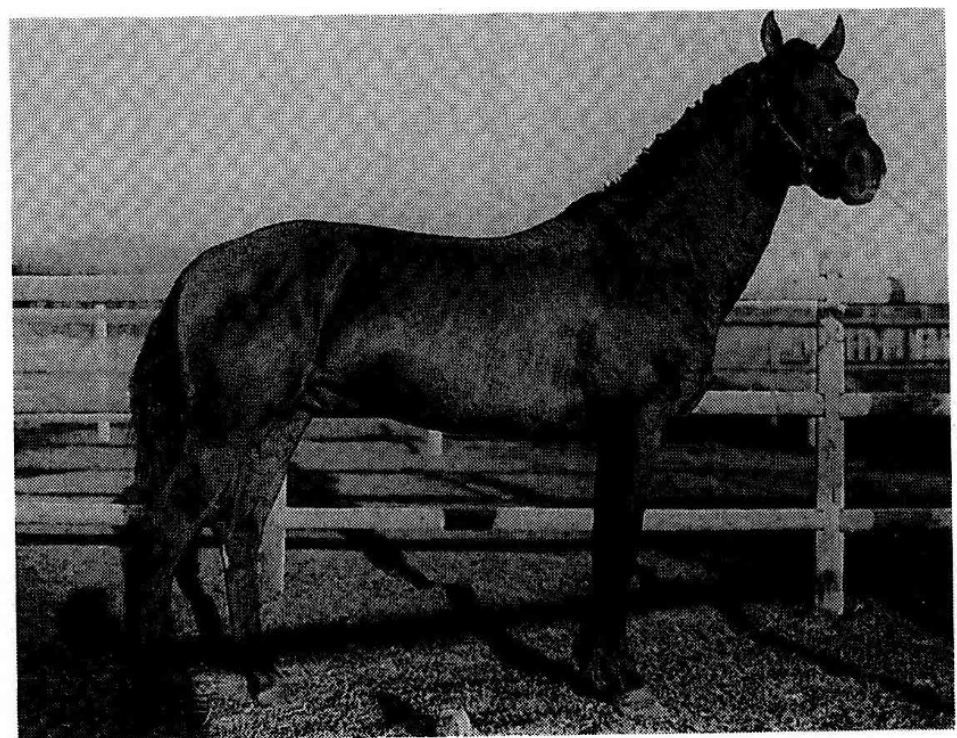




\section{DISCUSSION}

The recessive mode of inheritance for curliness in horses has been previously documented, and some curly horses are probably homozygous for this gene rather than attributable to the dominant gene. This is especially likely for the curly horses resulting from matings of purebred horses of breeds that are normal coated. In our data is one such curly Missouri Foxtrotter stallion born of normal coated parents. He produced 5 normal coated foals after being bred to normal coated horses. If his record is removed from the data of the curly and normal matings then the result is 29 curly and 12 normal foals. Under the hypothesis of heterozygosity for a dominant gene $\chi^{2}=7.048,1 \mathrm{df}, P<0.01$ which is highly significant. These matings therefore produce an excess of curly foals, which would occur if some horses in the sample were homozygous, rather than heterozygous, for curliness.

The breeding of curly horses is complicated by the fact that 2 separate genetic mechanisms can cause the curly coat. One of these is dominant, the other is recessive. It is likely that the 2 can be accurately differentiated on the basis of the annual shedding of the mane and tail. This is expected of the dominant gene for curliness, but not the recessive. The symbol $C r d$ is proposed for the dominant gene causing curliness (curly dominant).

\section{ACKNOWLEDGMENTS}

The authors thank the American Bashkir Curly Registry for providing these data.

\section{REFERENCES}

Blakeslee LH, Hudson RS, Hunt HR (1943) Curly coat in horses. $J$ Hered 34, $115-118$

Shchekin VA, Kalaev VV (1941) Inheritance of curliness in the horse. CR (Dokl) Acad Sci URSS, NS, Animal Breeding Abstracts (1940) 26, 262-263, 9: 7 